\title{
Geoperspective
}

\section{Climate-proofing the flood protection of the Netherlands}

\section{P. Vellinga ${ }^{1}$, N. Marinova ${ }^{1, *} \&$ J.M. van Loon-Steensma ${ }^{2}$}

1 Alterra, Wageningen University and Research Centre, P.0. Box 47, 6700 AA Wageningen, the Netherlands.

2 Department of Environmental Sciences, (chair group Earth System Science), Wageningen University and Research Centre, P.0. Box 47, 6700 AA Wageningen, the Netherlands.

* Corresponding author. Email: natasha.marinova@wur.nl

Manuscript received: February 2009; accepted: March 2009

\begin{abstract}
Global sea level is rising at an increased rate since the late 19th century as a result of rising global mean temperatures. This rise is geographically non-uniform, with substantial spatial differences, and in the latest decade faster than expected. New evidence suggests that more rapid changes than indicated in the Fourth IPCC report take place in the two large continental ice sheets, Greenland and Antarctica. Consequently, the projected sea level rise threatens low-lying countries like the Netherlands. The process of 'climate-proofing' the flood protection system of the country offers, however, new opportunities for innovative solutions, providing not only higher flood protection, but also possibilities for multifunctional land-use.
\end{abstract}

Keywords: sea level rise, climate-proof flood protection, broad dikes, Dutch Delta Committee, the Netherlands

\section{Introduction}

Climate change as a societal issue was raised for the first time during the international conference on climate change in Villach in 1985 and its certainties and uncertainties were assessed a few years later in the First IPCC report (IPCC, 1990). Now, 20 years later, the theory is increasingly supported by measurements (Solomon et al., 2007). The global average temperature is now $1^{\circ} \mathrm{C}$ higher than hundred years ago (Fig. 1). For the Netherlands the average temperature over the last ten years has been $2^{\circ} \mathrm{C}$ higher than the temperature in the beginning of 20th century (KNMI, 2008).

Burning of fossil fuels, large-scale deforestation, release of methane (mainly from agriculture) and drying peat lands are among the most important causes for this rapid worldwide temperature rise. These activities influence notably the carbon dioxide and methane fluxes, modifying the global carbon cycle. This alteration of the carbon cycle modifies in turn the radiation balance and through it the average temperature of the Earth. The human species is becoming a truly geological force, as the effect of their activities surpasses the natural effects of the changes of the Earth's orbit eccentricity, tilt and precession, causing the so called Milankovitch cycles.

IPCC infers in its Fourth assessment report (Solomon et al., 2007) that the concentrations of greenhouse gasses are expected to increase in the future, leading to further increase of temperature (Fig. 1). IPCC projections for the end of the 21st century have a broad range: from 1.5 tot $6^{\circ} \mathrm{C}$, yet the upper boundary remains a question of some debate as the impact of some feedbacks are still not incorporated in the projections and higher values cannot be ruled out.

Recent analysis by Hansen et al. (2008), based on the relations between palaeotemperature and changes of $\mathrm{CO}_{2}$ and the current emissions suggests, for example, that greenhouse gasses in the atmosphere at present are already at a level sufficiently high to ultimately cause global temperature rise of $6^{\circ} \mathrm{C}$ (see Fig. 2). The

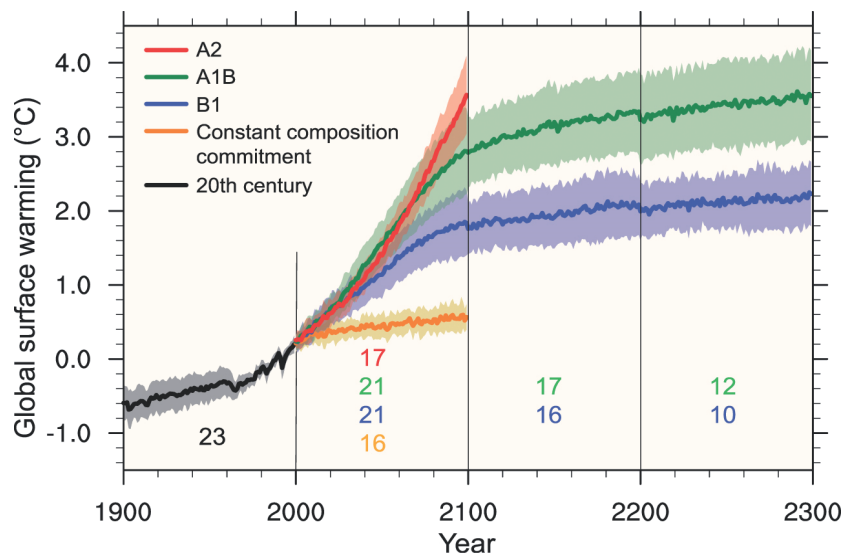

Fig. 1. Projections for global surface warming in 21st century for different scenarios, after Solomon et al., 2007. 
reason that this is not the case yet is that some feedbacks need decades before their full effects become observable, and because of the cooling effect of some aerosol pollutions. Scheffer et al. (2006) also argue that feedback mechanisms will shift the projected temperature range to $2-10^{\circ} \mathrm{C}$ by the end of 21st century.

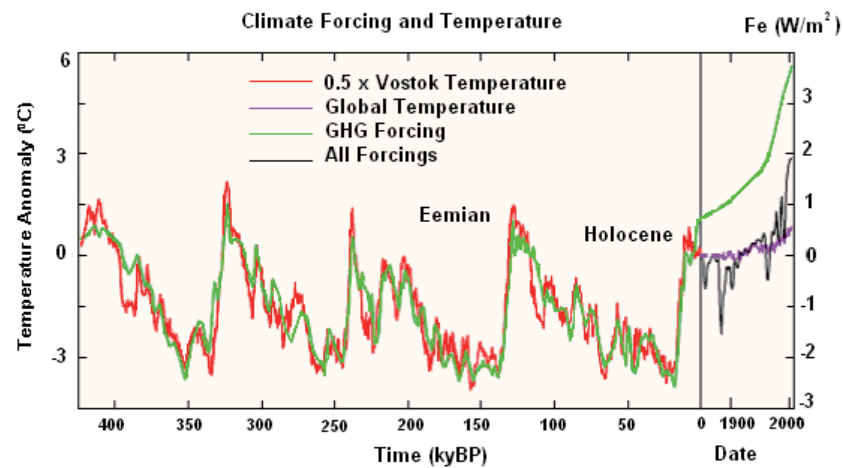

Fig. 2. Global temperature (left scale) and GHG forcing (right scale) due to $\mathrm{CO}_{2}, \mathrm{CH}_{4}$ and $\mathrm{N}_{2} \mathrm{O}$ from the Vostok ice core, after Hansen et al. (2008).

\section{Global warming and sea level rise}

Plotting the trends in global mean values of temperature and sea level suggests a close correlation, especially when considered on a decadal time scale (Fig. 3). Global sea level is rising at an increased rate since the late 19th century, after a period of little change during the last 2000 - 3000 years. Over the whole period from 1870 to 2000 this rate was $1.3 \pm 0.5 \mathrm{~mm} / \mathrm{yr}$, but in the period 1993 - 2003 there was even bigger acceleration, with observed changes of $3.1 \pm 0.7 \mathrm{~mm} / \mathrm{yr}$ (Solomon et al., 2007). Although there was a slow down in this trend during the last few years, these years are still among the ten warmest ones in the period of instrumental measurements (NASA, 2009).
Global temperature rise causes Arctic snow and summer sea ice cover to retreat presently at a greater rate than expected. Although this melting sea ice does not influence sea level directly, it triggers different feedback mechanisms that reinforce the effects of global climate changes. Changes in albedo of the ocean surface and modification of air and ocean circulation are feedbacks, leading to increased polar warming and hence to glacier and ice-sheet melting, coastal erosion and sea level rise (CCSP, 2009).

Main factors contributing directly to global sea level rise are thermal expansion of the ocean and melting of the ice sheets, ice caps and glaciers. On a local scale changes in salinity, atmospheric pressure, ocean circulations and land movements may lead in some regions to faster or slower sea level rise than the global average. Sea level rise is geographically non-uniform, with substantial spatial differences (see Fig. 4).

IPCC projected in its Fourth Assessment Report (AR4) a rise of between $0.18 \mathrm{~m}$ and $0.59 \mathrm{~m}$ for the global sea level at the end of 21st century, depending on greenhouse-gas emission scenarios. The largest contribution is expected to come from thermal expansion ( 0.10 to $0.41 \mathrm{~m}$ ), followed by glaciers and ice caps $(0.07$ to $0.17 \mathrm{~m})$ and the Greenland Ice Sheet (0.01 to $0.12 \mathrm{~m}$ ). In the IPCC report, the contribution from Antarctica is considered to be negative as a result of a prevailing accumulation, leading to sea level fall between 0.02 and $0.14 \mathrm{~m}$.

However, new evidence suggests that more rapid changes than indicated in the IPCC report took place in Greenland and Antarctic continental ice sheets (Fig. 5). The state-of-the-art climate models used by IPCC were not able to reproduce these changes, because some key processes and feedbacks of the ice sheets were still poorly understood. That is why IPCC chose for

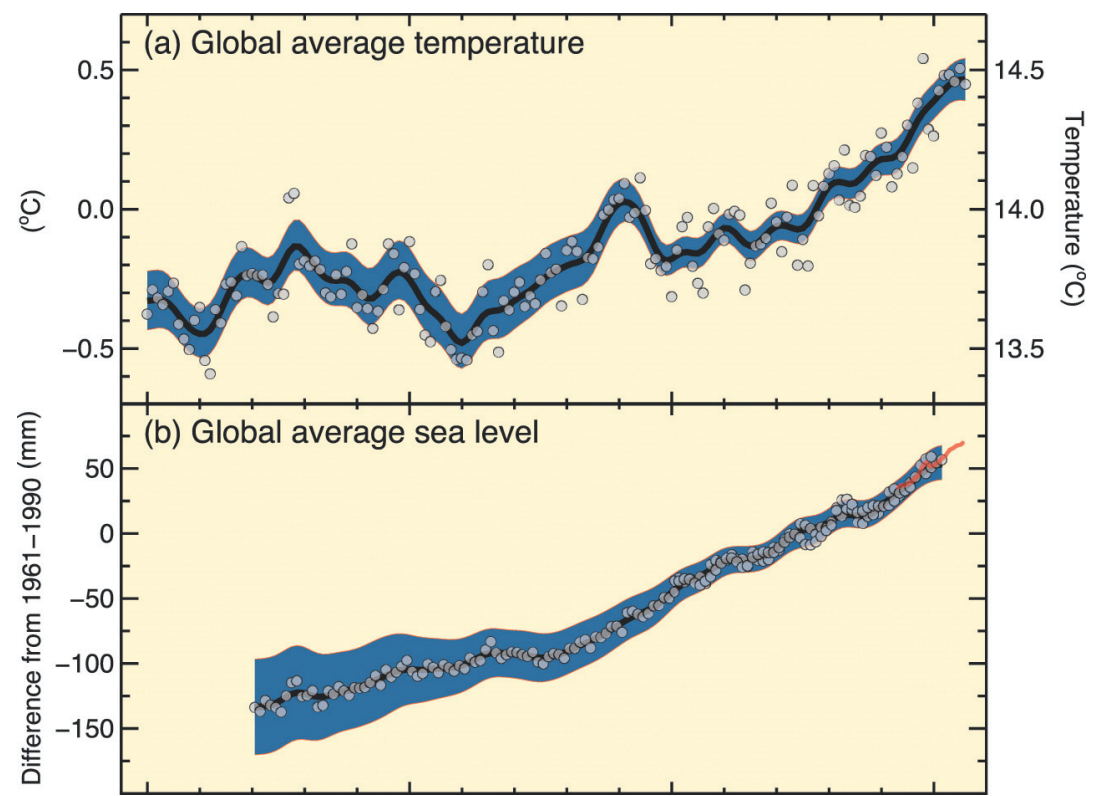

Fig. 3. Correlation between global temperature and global sea level rise, after Solomon et al., 2007. 
Fig. 4. Geographic distribution of long-term linear -60 trends in mean sea level (mm/yr) for 1955 to 2003 based on the past sea level reconstruction with tide gauges and altimetry data, after Solomon et al. (2007).

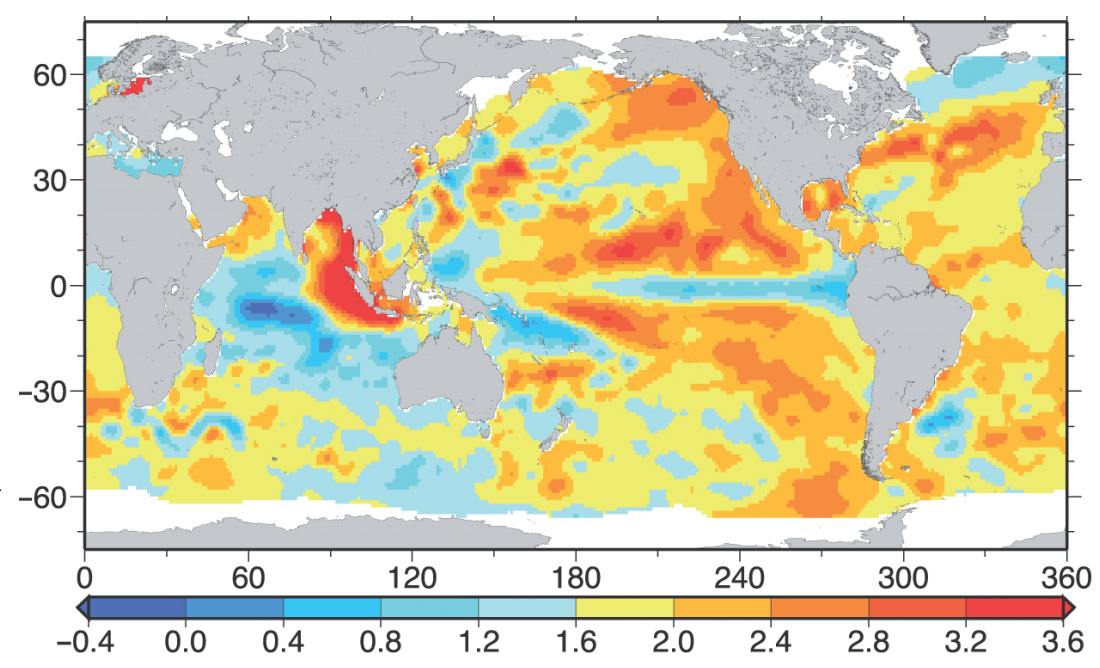

a compromise option to upscale this impact with global average surface temperature and adds 0.1 to $0.2 \mathrm{~m}$ to the projected upper boundary for sea level rise in 2100 .

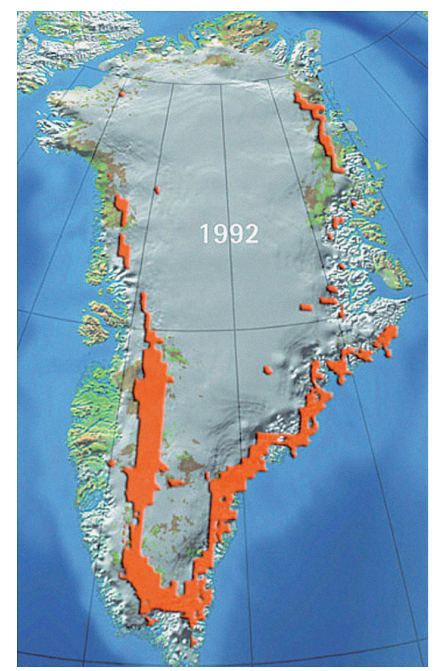

a.

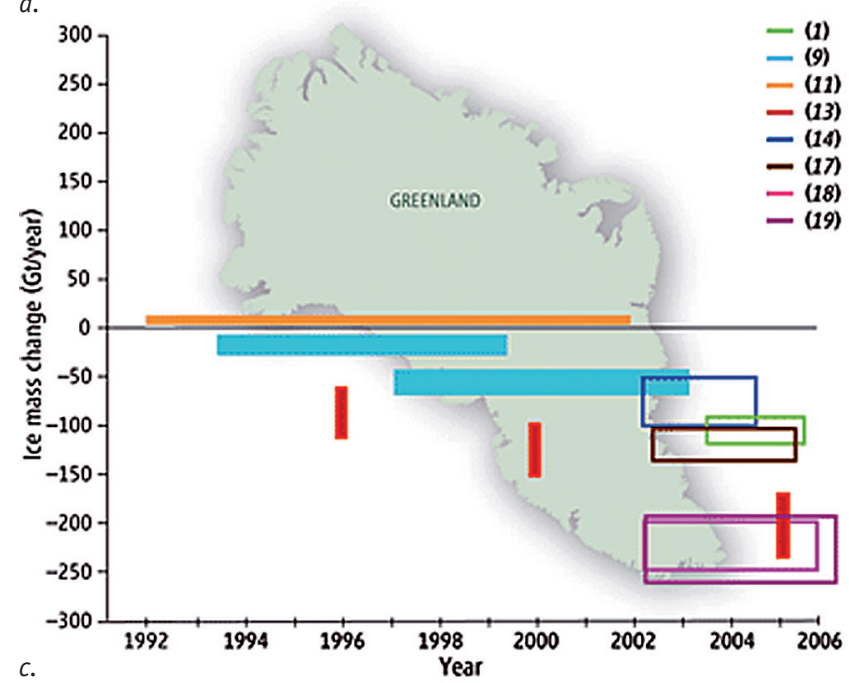

This approach to construct the upper boundary of the projections gave rise to extended debates, because the scaled-up values would not fully assess the positive feedbacks between

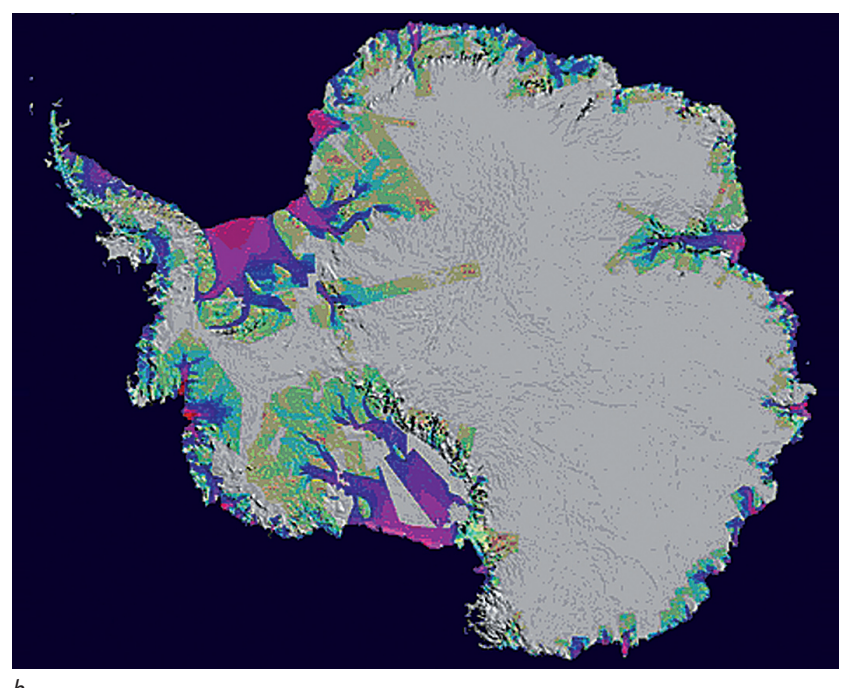

b.
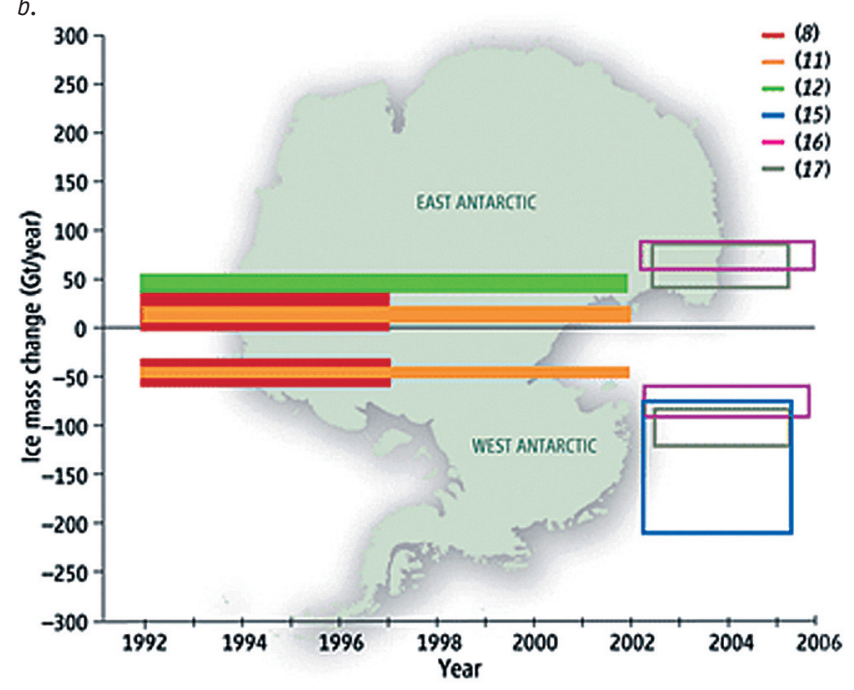

Fig. 5. a. Seasonal surface melt extent of Greenland Ice Sheet in the period 1992 - 2002, after ACIA (2004); b. Antarctic Ice Sheet between 1996 and 2006 , overlaid on a Moderate Resolution Imaging Spectroradiometer (MODIS) mosaic image of Antarctica. The colors indicate the speed of the ice loss. Purple/red is fast, green is slow (after NASA); c. Ice mass change of Greenland and Antarctic Ice sheets in the period 1992 - 2006, after Cazenave et al., 2006. 
ice sheet melting and sea level rise and hence the ice sheet contribution may well be underestimated. For instance Rahmstorf et al. (2007) compared the observations from tide gauges and satellite-altimeter since 1993 and concluded that the models reflected in the IPCC 2007 report underestimate sea level rise. Using a semi-empirical approach, Rahmstorf (2007) projects a rise in sea level of 0.5 to $1.4 \mathrm{~m}$ in 2100 .

Pfeffer et al. (2008) made an estimate of the absolute maximum rate of sea level rise if all potentially vulnerable glaciers around the edges of Greenland and Antarctica would rapidly melt. They found values for maximum possible sea level rise by 2100 ranging from 0.8 and $2.0 \mathrm{~m}$ Pfeffer et al. (2008) used simple physical considerations and combinations of contributions from Greenland and Antarctica based on varying glacier velocities (but taking also into consideration the two other major sources of sea level rise: thermal expansion and small glaciers and ice caps) to construct their set of scenarios for sea level rise in 2100.

Evidence from palaeorecords indicates that rates of sea level rise as discussed above (and even higher) have occurred in Earth history under comparable climate conditions. During the Last Interglacial stage, called Eemian, about 125,000 years ago, global mean temperatures were probably 2-30C higher than today (see Fig. 2), while sea level was about $10 \mathrm{~m}$ higher. Using a relative high resolution data set, constructed from oxygen isotopes and the coral data from the Red Sea, Rohling et al. (2008) concluded, that sea level rose from 0.7 to $1.7 \mathrm{~m} /$ century over intervals when the major contribution came from ice sheets of the scale of Greenland and West Antarctic Ice Sheets. Higher rates within periods of 300 years (the temporal resolution of the data set) cannot be ruled out.

\section{State of the flood protection in the Netherlands}

For the Netherlands, the projected sea level rise is crucial, because major parts of the country are situated below present sea level. Currently there is a debate about the issue whether it is wise to continue urban development in the polders, lying $5 \mathrm{~m}$ or more below sea level. Should we continue to build higher and higher dikes, or would it be better to move to the higher areas in the Eastern part of the country? This debate includes the issue of financing of flood protection works (see Adviescommissie Financiering Primaire Waterkeringen, 2006). According to the 5-yearly review of the quality of the dikes, $19 \%$ of the Dutch flood protection works do not comply with the present day legal safety standards. This percentage is probably higher, because for $35 \%$ of the remaining flood protection works there are not sufficient data to evaluate the quality (see Table 1).
Table 1. Results from the review of the quality of the flood protection works of the Netherlands in 2001 and 2006, source: Adviescommissie Financiering Primaire Waterkeringen, 2006.

\begin{tabular}{|c|c|c|c|c|}
\hline \multirow[t]{3}{*}{ Category } & \multicolumn{4}{|c|}{ Results from the dike tests } \\
\hline & \multicolumn{2}{|l|}{2001} & \multicolumn{2}{|l|}{2006} \\
\hline & in $\mathbf{k m}$ & in $\%$ & in $\mathbf{k m}$ & in $\%$ \\
\hline Do not comply & 549 & 15 & 680 & 19 \\
\hline Not evaluated/insufficient data & 1217 & 34 & 1329 & 35 \\
\hline Comply with legal standards & 1792 & 50 & 1590 & 46 \\
\hline Total & 3558 & & 3599 & \\
\hline
\end{tabular}

Historically, the strengthening of Dutch flood protection works shows a clear cyclic development. A major, catastrophic flooding is usually followed by a significant intensification of the investments in dike safety. After approximately 50 years the vulnerability to flooding increases, followed by the next catastrophe. In general, major catastrophes in the Dutch history occur roughly every 100 years.

The fact that for $50 \%$ of the Dutch dikes it is uncertain whether they meet the legal safety standards for flood protection works, confirms the cyclical pattern in the dike enforcement. About 50 years after the disastrous flood of 1953 the crucial importance of keeping the dikes compliant with the safety requirements has disappeared from the collective memory. This observation is confirmed by the shortage of funds allocated. In 2007 independent analyses revealed that there is a gap of approximately one billion euro per year between the available financial means and the financial means necessary to make the dikes compliant with the law (Adviescommissie Financiering Primaire Waterkeringen, 2006, see also Fig. 6).

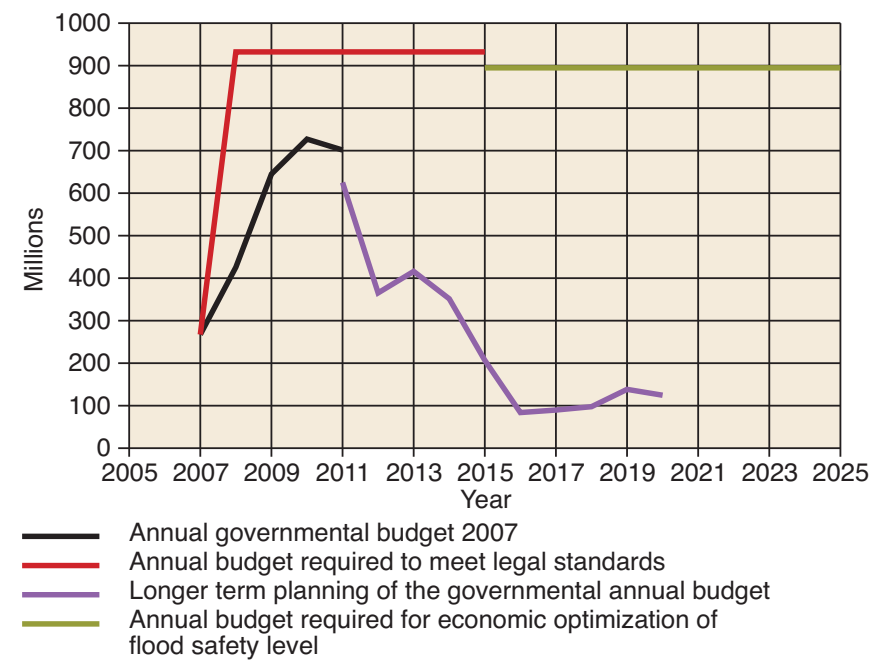

Fig. 6. Annual budget, necessary to make the Dutch dikes compliant with the law (Wet op de waterkering), after Adviescommissie Financiering Primaire Waterkeringen (Commissie Vellinga), 2006. 


\section{Scenarios, developed for the Delta Committee}

The discovery of shortcomings in the Dutch flood protection management, combined with climate change projections raised serious concerns in the Dutch government and led to the establishment of the second Delta Committee (the first one was established after the flooding in 1953) by the end of 2007. The Delta Committee was aware that the projections of both IPCC (Solomon et al., 2007) and of the Dutch Met Office (KNMI, 2006) did not cover the full range of the expected temperature and sea level rise. Therefore, it commissioned an international assessment, which main goal was to develop low-probability/highimpact scenarios, covering the upper boundaries of global and local sea level, storm surge and river Rhine projections for 2100 and 2200 (Vellinga et al., 2008). This assessment served as one of the background documents for the Delta Commission report (Deltacommissie, 2008).

The global world emissions have been accelerating in the latest years at higher rates than projected (Fig. 7). Therefore the scenarios, developed for the Delta Committee, also considered the possibility of the upper boundary IPCC scenario of $6^{\circ} \mathrm{C}$ rise in the global temperature in 2100 . The suggested ranges for this assessment, based on modelling and expert judgement, are $0.55-1.10 \mathrm{~m}$ for global mean sea level rise (Fig. 8) and 0.05 to $1.25 \mathrm{~m}$ for local sea level rise in 2100. For 2200 the ranges are 1.5 to 3.5 and $0.5-4 \mathrm{~m}$, respectively. The upper boundaries of the projections made for the Delta Committee are within the abovementioned ranges of Rahmstorf (2007) and Pfeffer et al. (2008). They are also within the ranges given by another advisory bodies, like the German Advisory Council on Global Change (WBGU, 2006) and the Californian Delta Vision Task Force (personal communications) (Fig. 9).

The major short-term threat for low-lying countries like the Netherlands does not come from steady rising sea levels (this

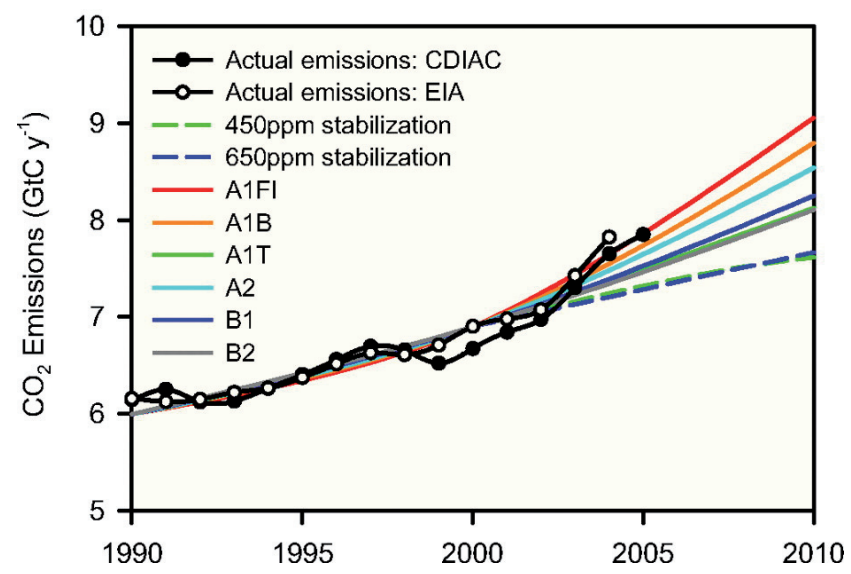

Fig. 7. World greenhouse gas emissions for 2005, 2006 and 2007, adapted from Raupach et al., 2007.

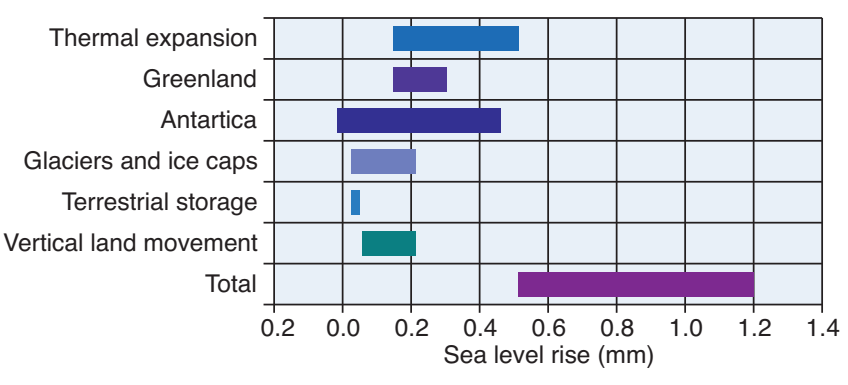

Fig. 8. Projections for global mean sea level rise in 2100, after Katsman et al. in Vellinga et al. (2008).

can be anticipated by raising dikes), but from sudden extreme storm surges. As a standard, Dutch law requires coastal protection works to withstand water levels that occur once in 10,000 years. The corresponding 1-in-10,000 surge level is not a static number, however - it can change due to climate change, sedimentation and erosion. For the assessment by Vellinga et al. (2008) the existing studies of the effect of climate change on surge levels were analysed. The conclusion was that despite the small increase in wind speed, the surge levels remain centered around their present values (Sterl et al. in Vellinga et al., 2008). There is a big uncertainty in the storm surge projections, however, because conclusions for 1-in-10,000 event are based on only 150 years of observations.

One recent discovery may help to extend the current extreme event statistics. The storm on November 9, 2007 eroded about $10 \mathrm{~m}$ of the coastal dunes near Heemskerk and exposed shellrich layers (Van Heteren et al., 2008). A follow-up study revealed that the shell layer originated from a storm-surge with a height of possibly $6.5 \mathrm{~m}$ above mean sea level. The approximate time this storm surge occurred is estimated to be in the interval from 1650 to $1850 \mathrm{AD}$. Further study of such proxy records may contribute to the improvement of 1-in-10,000 years event's calculations.

Not only the sea, but also the river Rhine also bears a potential threat due to its ability to cause devastating floods. Therefore it is important to know how climate change will affect the relevant discharge characteristics of the river and a 1-in-1250 return event, called 'design value' and presently corresponding with a peak discharge of $16,000 \mathrm{~m}^{3} / \mathrm{s}$. According to the projections, it may rise to 16,500 to $19,000 \mathrm{~m}^{3} / \mathrm{s}$ in 2050 and 17,000 to $22,000 \mathrm{~m}^{3} / \mathrm{s}$ in 2100 as a result of climate change. The relative change in the 1250-year peak discharge is thus 3 to $19 \%$ for 2050 and 6 to $38 \%$ for 2100 (Table 2). These estimates are based on the assumption, that there will be an enforcement of the river dikes in Germany. 


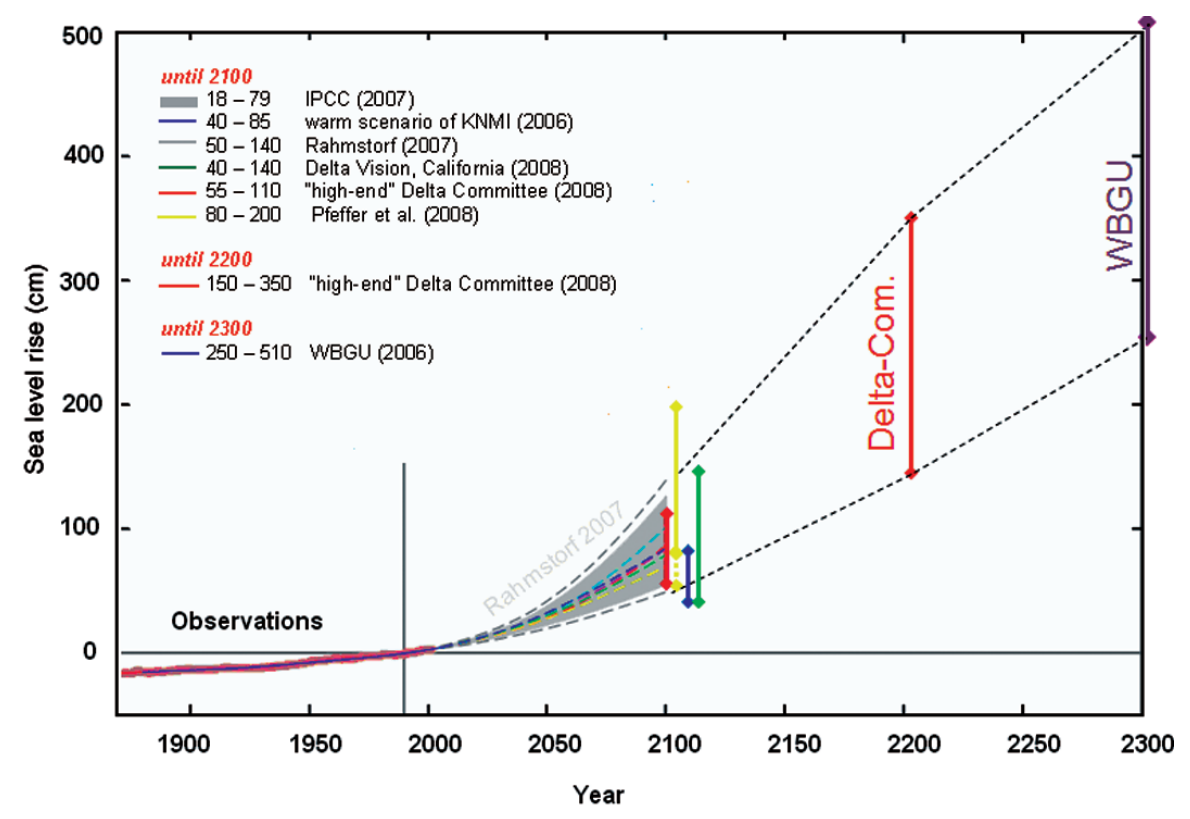

Fig. 9. Sea level projections, made by IPCC, KNMI, Delta Comission, WBGU, Delta Vision Task Force, Pfeffer and Rahmstorf, after Rahmstorf (personal communications) and Vellinga (2008).
Table 2. Estimates of changes in the peak discharge of the Rhine $\left(\mathrm{m}^{3} / \mathrm{s}\right)$ in 2050 and 2100. The reference value refers to the 1250-year discharge at Lobith, after Beersma et al. in Vellinga et al., (2008).

\begin{tabular}{|c|c|c|c|c|}
\hline & $\begin{array}{l}\text { Reference } \\
\text { value }\end{array}$ & 2050 & 2100 & 2200 \\
\hline Peak discharge $\left(\mathrm{m}^{3} / \mathrm{s}\right)$ & 16,000 & $16,500-19,000$ * & * $17,000-22,000$ & n.a. \\
\hline Change in $\%$ & & $3-19$ & $6-38$ & n.a. \\
\hline
\end{tabular}

\section{Climate-proof flood protection}

Although future projections are accompanied by large uncertainties, it is clear that climate change will have a serious impact on longer term safety of the Netherlands. In response to this threat various adaptation strategies can be considered. For sea level rise three main strategies can be distinguished:

- 'Forward defence' - building a high strong dike far into the sea in front of the Dutch coast from Cadzand to Borkum (Fig. 10a);

- 'Selective withdrawal' of people and investment to the higher areas (Fig. 10b);

- Defence of the present contours of the Netherlands in 2 variants: open and closed estuaries (Fig. 10c and d);

The Delta Committee dismissed the first two options and recommended in its report to the Dutch cabinet of ministers the third strategy: defence of present contours, with open estuaries. This option is more flexible in long term as the rivers flow freely into the sea and this strategy provides a better environmental quality.
The open estuary can be realised in different ways: strengthening the existing dike rings by raising the dikes (Fig. 11a); introducing a multitude of smaller dike rings (so called compartimentation) (Fig. 11b); elevating the surface in the low-lying areas (Fig. 11c); building broad, unbreakable dikes (Fig. 11d). Although each of the four options has its own advantages and disadvantages (Table 3 ), broad dikes appear to be the winner because of the significantly lower damages in case of extreme high waters. In case of overflowing the damage increases gradually with higher surge levels and not abruptly as it is by the narrow dikes that will collapse in case of overflowing (Fig. 12). Moreover, the broad dike concept allows for additional user functions like urbanisation, recreation, nature management and even agriculture to be combined with flood protection works.

\section{Innovative dike building}

As pointed out in the previous paragraphs, there is ample attention for flood-safety in the Netherlands. Not only plans, but also significant investments are being made in innovative flood protection works, including 'climate-proof ' dike systems. The common idea behind 'climate proof' flood protection works (dikes) is that they do not collapse when the water overflows their top. Various names, given to them, such as 'Delta Dike', 'Climate Dike' and 'Broad Dike' reflect this design principle. These names and concepts refer to robust dikes, whose width, height or internal structure make them so strong, that the risk of total failure and subsequent total inundation is virtually zero, even when the flood level is temporarily higher than the top of the dike. Even under changing climatic conditions with 

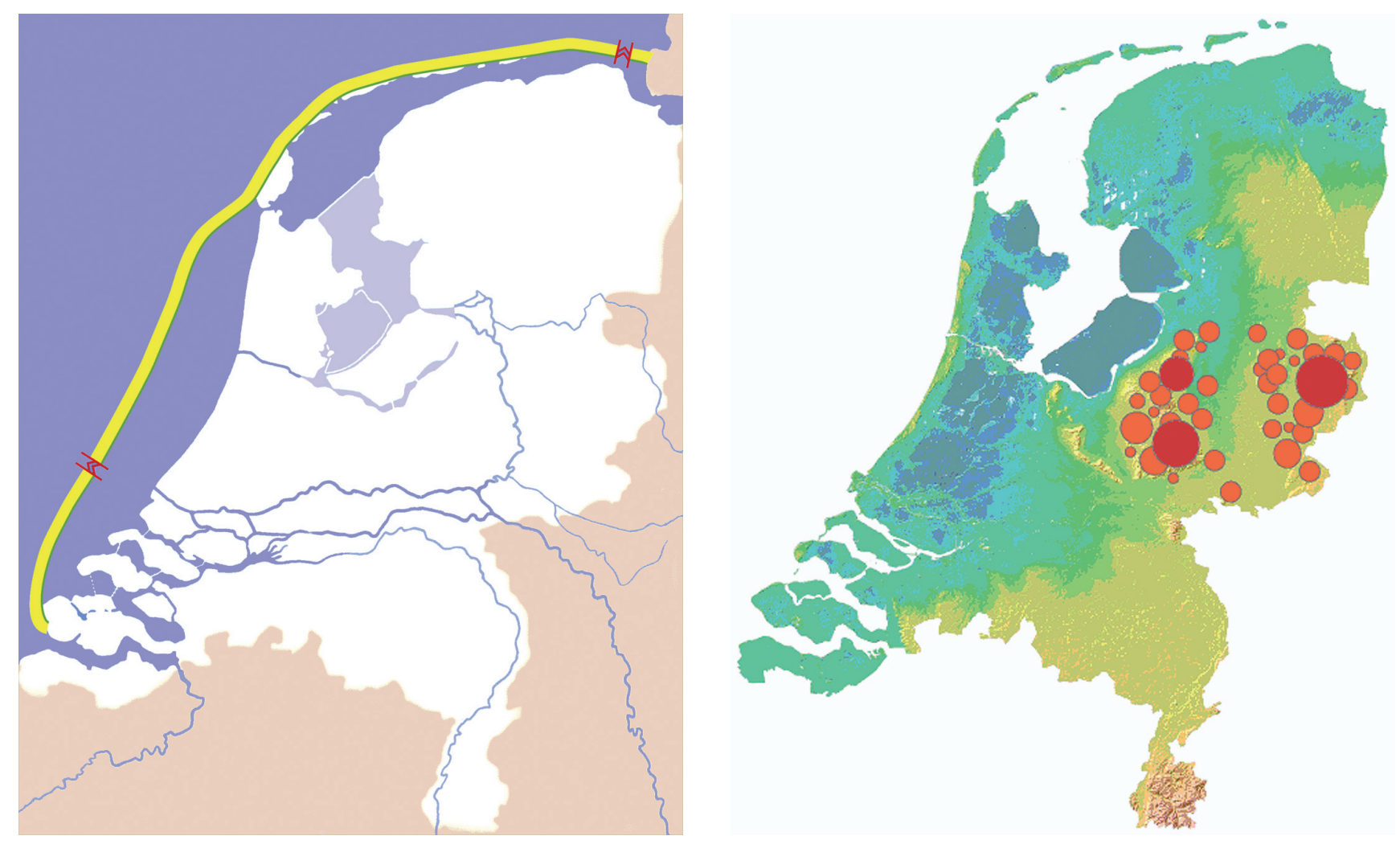

a.

b.
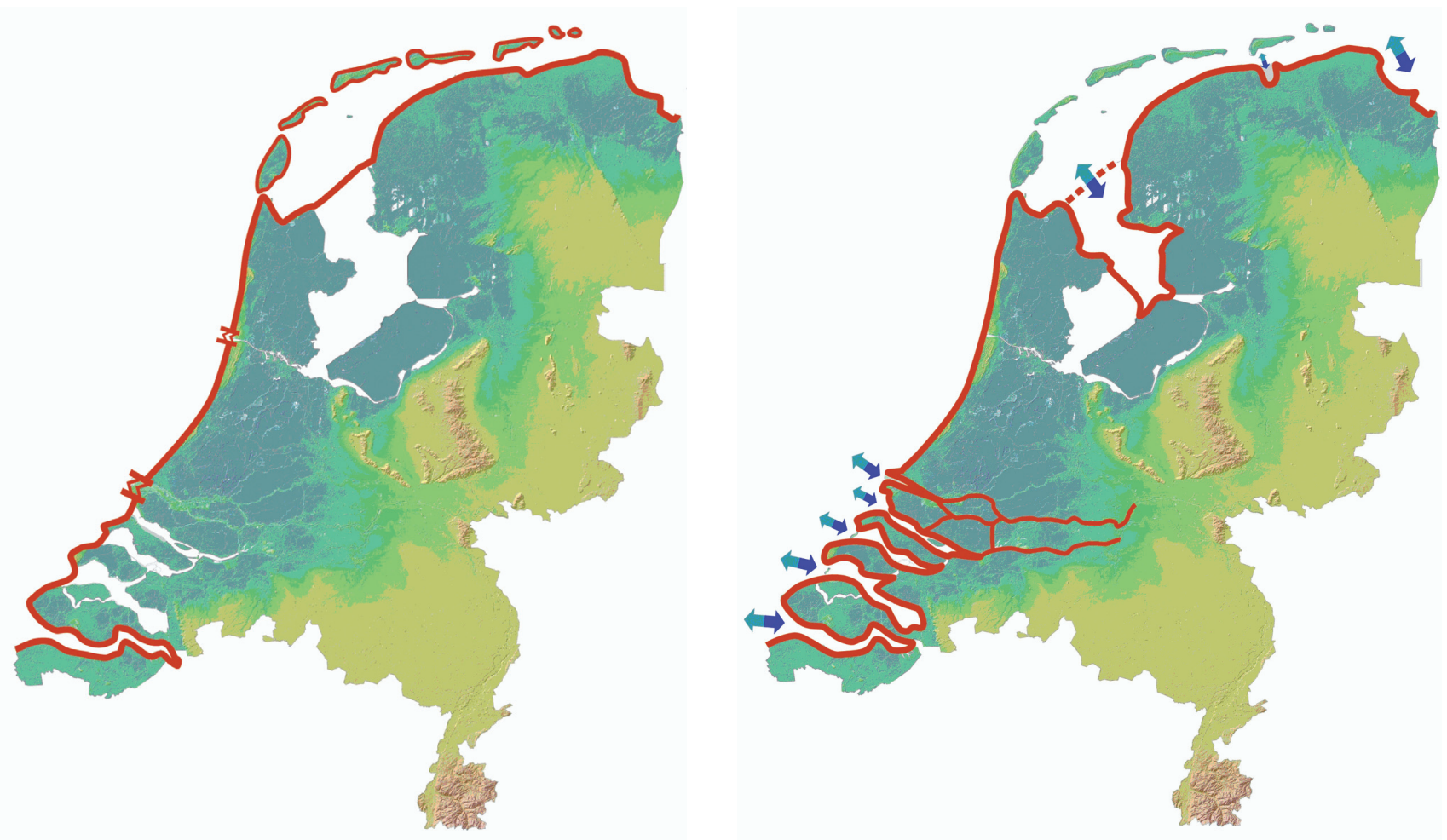

d.

Fig. 10. Different strategies for flood protection: $a$. forward defence; $b$. moving to higher areas; $c$. present contour with closed estuaries; and $d$. present contour with open estuaries, after Vellinga (2008). 

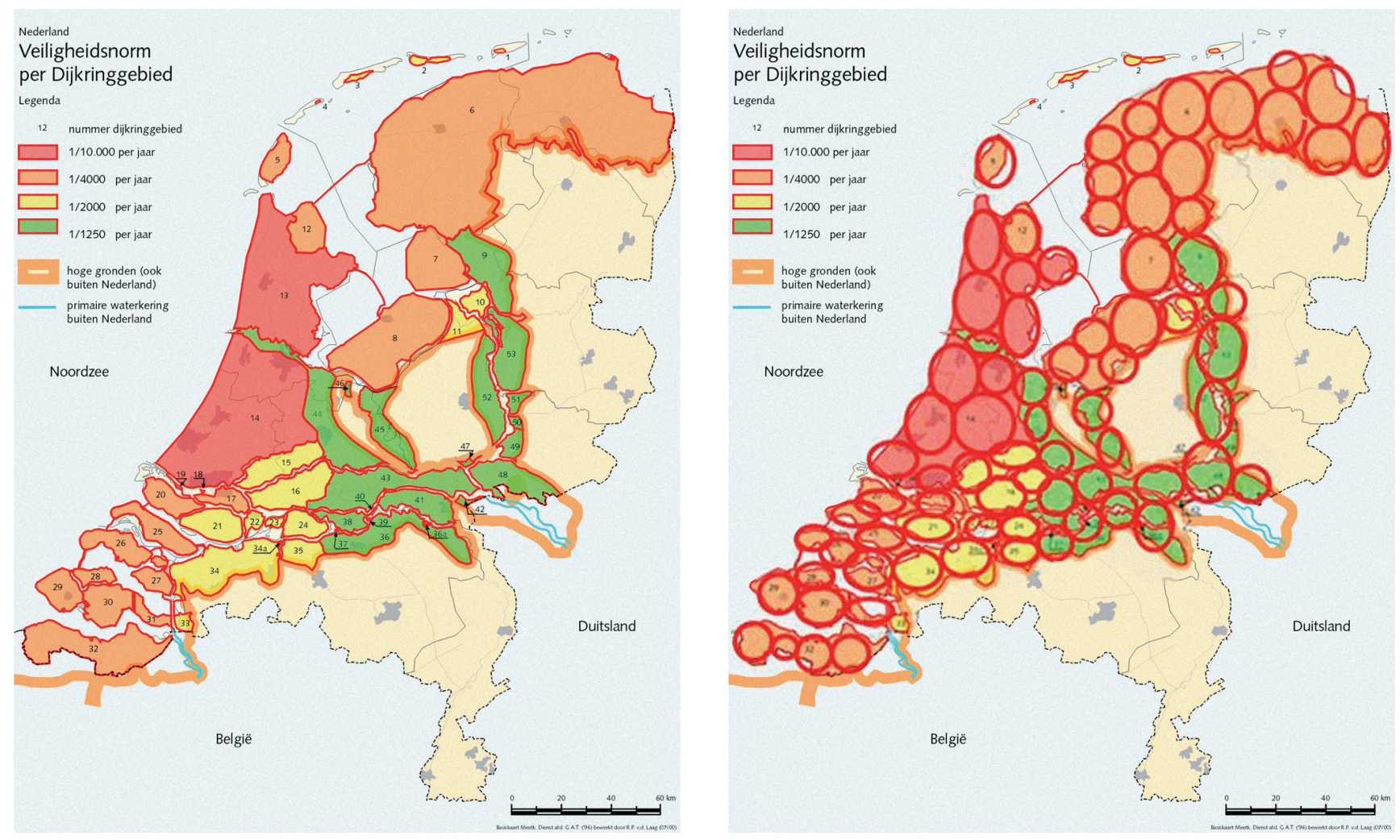

$b$.
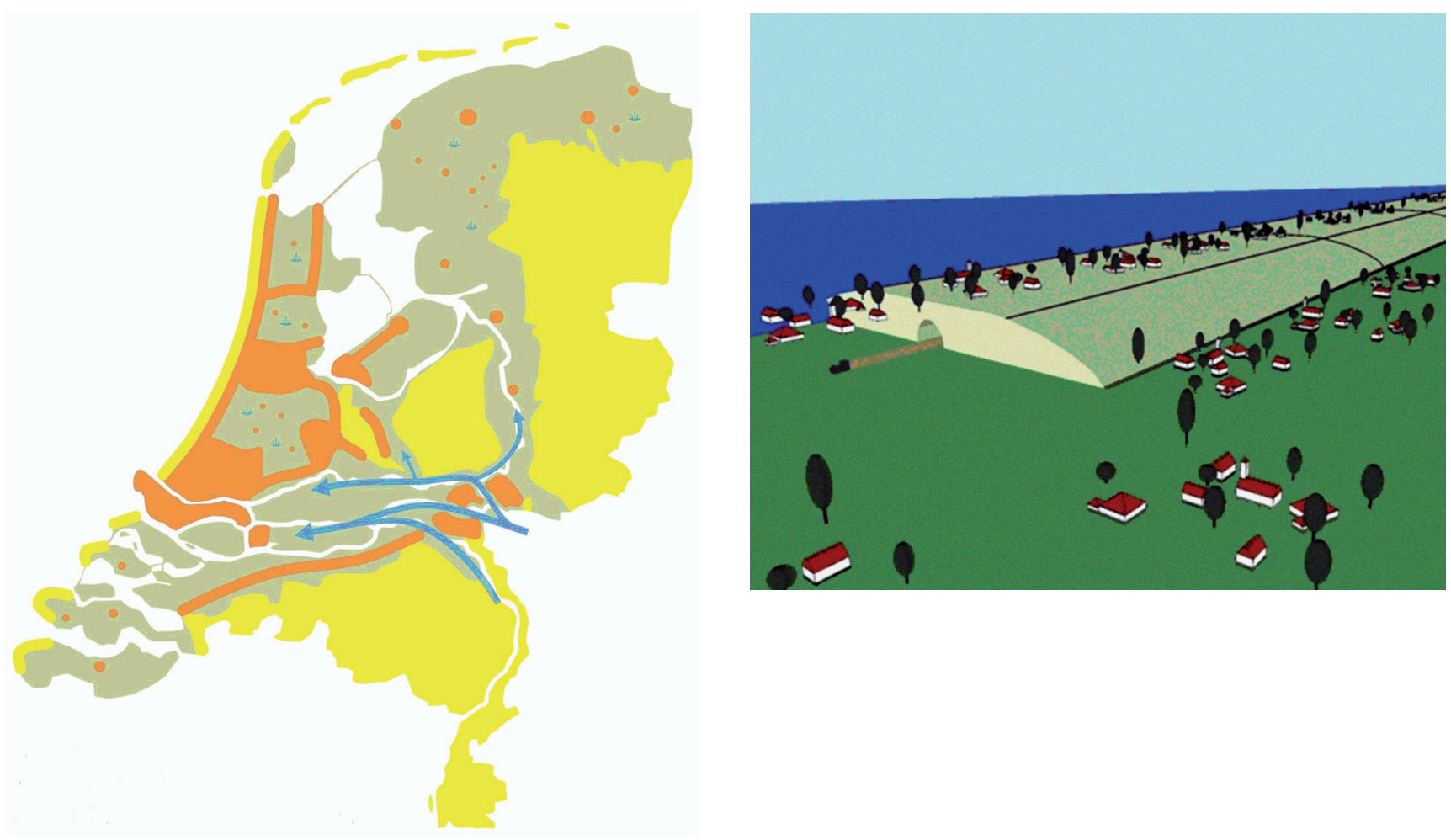

d.

Fig. 11. Different options for realisation of open dikes: $a$. with big raised dike rings; $b$. with smaller dike ring; c. elevating the surface in the low-lying areas; and d. broad, unbreakable dikes. 
Table 3. Advantages and disadvantages of different types open dikes, after Vellinga, 2008.

\begin{tabular}{|c|c|c|c|c|}
\hline & Raised rings & Smaller dike rings & Elevating the land surface & Broad unbreakable dikes \\
\hline Advantages & $\begin{array}{l}\text { Mono-functional, relative } \\
\text { easy to maintain }\end{array}$ & $\begin{array}{l}\text { Limited damages if a dike } \\
\text { breaks }\end{array}$ & $\begin{array}{l}\text { Is technically feasible and } \\
\text { provides maximum protection, } \\
\text { also in a long term }\end{array}$ & $\begin{array}{l}\text { Limits considerable the number } \\
\text { of victims and damages; } \\
\text { Is technically feasible } \\
\text { Is less costly than the b and c options } \\
\text { Provides higher protection } \\
\text { Offers new space use and economical } \\
\text { possibilities }\end{array}$ \\
\hline Disadvantages & $\begin{array}{l}\text { If water level surpasses } \\
\text { the design level, the dike } \\
\text { will collapse, with large } \\
\text { scale and long-term } \\
\text { inundation as a result }\end{array}$ & $\begin{array}{l}\text { 1. Requires more space } \\
\text { and is more difficult } \\
\text { to maintain } \\
\text { 2. The result is a smaller } \\
\text { flooded area but more } \\
\text { victims as the water } \\
\text { rises relatively fast }\end{array}$ & $\begin{array}{l}\text { 1. Requires a lot of sand/soil } \\
\text { 2. Difficult to realise, with an } \\
\text { exception for newly build } \\
\text { and renovated urban areas }\end{array}$ & $\begin{array}{l}\text { Its realisation requires serious long- } \\
\text { term determination, planning and } \\
\text { investment }\end{array}$ \\
\hline
\end{tabular}

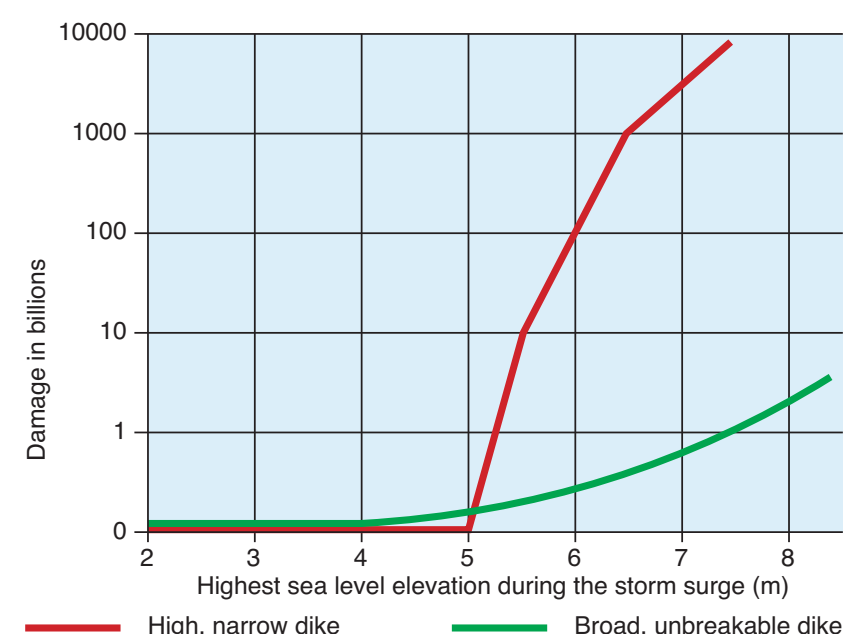

Fig. 12. Damage functions of narrow (red) and broad (green) dike, after Vellinga, 2008.

unknown extreme storm surge and river discharge levels such dikes provide adequate safety. Another innovative characteristic of such climate-proof dikes is the possibility to combine their basic function (flood protection) with other (land-use) functions like housing, creation of natural parks, recreation, and agriculture or transport infrastructure. This obviously requires location-specific designs.

Silva and Van Velzen (2008) made a quick scan of the monetary costs of broadening the existing dikes into 'climate proof' ones. They conclude that the current dikes can be made unbreakable with relatively moderate financial means. The total costs for converting the present dikes along the coast, estuaries and large rivers are estimated at $6.5 \times 10^{9}$ euro. When an additional rise of $0.5 \mathrm{~m}$ in extreme surge levels and river peak discharge levels is taken into account, the costs would rise with additional $5 \times 10^{9}$ euro. In comparison, the Netherlands annual gross domestic product is about $600 \times 10^{9}$ euro. When implemented over 20 years time, the monetary cost of 'climate proofing the major part of the Netherlands flood protection works would be in the order of 0.1 percent of annual GDP. In reality the cost are likely to be higher because land use changes in a highly populated country such as the Netherlands are accompanied by high transaction cost. However the quick scan of technical and monetary aspects illustrates that protecting our country against flooding even in times of rising seas and increasing river levels is technically and economically feasible. Moreover, the coastal protection strategy with open estuaries as recommended by the Delta Committee and the new dike concepts illustrate that the challenges of climate change can be a trigger for innovation with new benefits.

\section{References}

ACIA, 2004. Impacts of a Warming Arctic: Arctic Climate Impact Assessment, Cambridge University Press, online publication on www.acia.uaf.edu, last accessed on 20 Feb. 2009.

Adviescommissie Financiering Primaire Waterkeringen (commissie Vellinga), 2006. Tussensprint naar 2015, Rotterdam: 74 pp, online publication on www.verkeerenwaterstaat.nl/Images/br\%2E1498\%2Ebijlage_tcm195-170529.pdf, last accessed on 20 Feb. 2009.

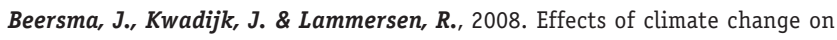
the Rhine discharges. In: Vellinga, P., Katsman, C.A., Sterl, A. \& Beersma, J. (eds): Exploring high end climate change scenarios for flood protection of the Netherlands: An international scientific assessment (in press). 
Cazenave A., 2006. How Fast Are the Ice Sheets Melting? Science 314: 1250-1252. CCSP, 2009. Past Climate Variability and Change in the Arctic and at High Latitude. A report by the U.S. Climate Change Program and Subcommittee on Global Change Research, Alley, R.B., Brigham-Grette, J., Miller, G.H., Polyak, L. \& White, J.W.C. (coordinating lead authors). U.S. Geological Survey, Reston, VA: $461 \mathrm{pp}$.

Deltacommissie, 2008. Samen werken met water, Bevindingen van de Deltacommissie, $134 \mathrm{pp}$

Hansen, J., Sato, Mki., Kharecha, P., Beerling, D., Berner, R., Masson-Delmotte, V., Pagani, M., Raymo, M., Royer, D.L. \& Zachos J.C., 2008. Target atmospheric $\mathrm{CO}_{2}$ : Where should humanity aim? Open Atmospheric Science Journal 2: 217-231.

Katsman, K., Church, J., Kopp, R., Kroon, D., Oppenheimer, M. Plag, H.-P., Rahmstorf, S., Ridley, J., von Storch, H., Vaughan, D. \& Van der Wal, R., 2008. Sea Level Rise. In: Vellinga, P., Katsman, C.A., Sterl A. \& Beersma, J. (eds): Exploring high end climate change scenarios for flood protection of the Netherlands: An international scientific assessment (in press).

Klein Tank, A.M.G., Bessembinder, J.J.F., Van den Hurk, B.J.J.M. , Lenderink, G., Van Ulden, A.P., Van Oldenborgh, G.J., Katsman, C.A., Van den Brink, H.W., Keller, F., Burgers, G. , Komen, G.J., Hazeleger W. \& Drijfhout, S.S., 2006. Climate in the 21st century; four scenarios for the Netherlands. KNMI publication: $82 \mathrm{pp}$.

NASA, 2009. Antarctic Ice Loss Speeds Up, Nearly Matches Greenland, www.nasa.gov/topics/earth/features/antarctica-20080123.html, last accessed on 16 March 2009.

NASA, 2009. GISS Surface Temperature Analysis, online publication at data.giss.nasa.gov/gistemp/2008/, last accessed on 16 March 2009.

Pfeffer, W.T., Harper, J.T. \& O'Neel, S., 2008. Kinematic Constraints on Glacier Contributions to 21st-Century Sea-Level Rise. Science 321: 1340-1343.

Rahmstorf, S., Cazenave, A., Church, J., Hansen, J., Keeling, R., Parker, D. \& Somerville, R., 2007. Recent Climate Observations Compared to Projections. Science 316: 709 .

Rahmstorf S., 2007. A Semi-Empirical Approach to Projecting Future Sea-Level Rise. Science 315: 368-370.

Rohling, E.J., Grant, K., Hemleben, C., Siddall, M., Hoogakker, B.A.A., Bolshaw, M., \& Kucera, $M_{\text {., }}$ 2008. High rates of sea-level rise during the last interglacial period. Nature Geoscience 1: 38-42.

Raupach, M.R., Marland, G., Ciais, P., Le Quere, C., Canadell, J.G., Klepper, G. \& Field, C.B., 2007. Global and regional drivers of accelerating $\mathrm{CO}_{2}$ emissions. Proceedings of the National Academy of Sciences 104: 10288-10293.

Scheffer M., Brovkin V. \& Cox P.M., 2006. Positive feedback between global warming and atmospheric $\mathrm{CO2}$ concentration inferred from past climate change. Geophysical Research Letters 33, L10702.

Silva, W. \& Van Velzen, E., 2008. De dijk van de toekomst? Quick scan Doorbraakvrije dijken, Rapport 2008.052 Ministerie van Verkeer en Waterstaat, DG Water: $85 \mathrm{pp}$.
Solomon, S., Qin, D., Manning, M., Chen, Z., Marquis, M., Averty, K., Tignor, M \& Miller, H., Climate Change 2007: The Physical Science Basis. Contribution of Working Group I to the Fourth Assessment Report of the Intergovernmental Panel on Climate Change. Solomon, S., Qin, D. \& Manning M. (eds), Cambridge, UK: Cambridge University Press: 996 pp.

Sterl, A., Weisse, R., Lowe, J. \& Von Storch, H., 2008. Winds and storm surges along the Dutch coast, In: Vellinga, P., Katsman, C.A., Sterl, A. \& Beersma, J. (eds): Exploring high end climate change scenarios for flood protection of the Netherlands: An international scientific assessment (in press).

Van Heteren S., Bakker M.A.J., Oost A.P., Van der Spek A.J.F. \& Van der Valk, L., 2008. Sedimentary Signature of a Storm-surge Unit in the western Netherlands coastal Dunes Geophysical Research Abstracts 10, EGU2008-A-10264.

Vellinga P., 2008. Hoogtij in de Delta, inaugural lecture, Wageningen University, 16 0ctober 2008: 52 pp.

Vellinga, P., Katsman, C.A., Sterl A. \& Beersma J. (eds), 2008.Exploring high end climate change scenarios for flood protection of the Netherlands: An international scientific assessment (in press).

WBGU, 2006. The Future 0ceans - Warming Up, Rising High, Turning Sour Berlin: 110 pp., online publication at www.wbgu.de/wbgu_sn2006_en.html, last accessed on 20 Feb. 2009. 